\title{
5'-NUCLEOTIDASE ACTIVITY IN GERTAIN TISSUES OF THE FISH HETEROPNEUSTES FOSSILIS UNDER TOXIC STRESS
}

\author{
S. NARAIN AND B. KUMAR \\ P. G. Department of Zoology, Janta College Bakewar (Etawah)-206 124, India
}

Received for publication November 29, 1991

\begin{abstract}
The present study deals with the effects of Urea, Nirma, DDT and Malathion in combination on 5'nucleotidase activity in the liver, kidney intestine and gills of a fresh water teleost Heteropneustes fossilis at sublethal levels after short term and long term exposure. Marked alteration in 5 '-nucleotidase activity were noted at most of the concentrations. Significant stimulation of enzyme activity was observed in the kindey. In the gills a notable synergistic effect was the presence of dense deposits of 5 -nucleotidase reaction product in the pillar cells of alternate gill lamina in the treated specimens. The most remarkable feature observed was that the enzyme leaves the area of operation by leaving the membrane system of its anchorage subsequent to the treatment of above mentioned contaminants and pollutants.
\end{abstract}

These days the dischange of common aquatic contaminants and pollutants into nearby bodies of water including the sea, is causing anxiety because it endangers the living organisms including fish, which are considered to be one of the most sensitive groups. The efffects of stress induced by toxicants on aquatic life have been reviewed by Abel (1), Shaffi (9), Gupta et al. (3), Zaccone et al. (11), Mehra and Kanwar (5) and Richard et al (8). However, cytochemically the events have not been extensively proven and it is necessary to study the chronic effects of sublethal concentrations of various pollutants and their constituents which result in the gradual elimination of various animal species. Liver, kidney, intestine and gills are the prime target for the damaging action of xenobiotic chemicals (4). Researchers have, in fact, observed various levels of injury in the above tissues of the fish from polluted environment. The present investigation was undertaken to determine the synergistic effects of a chemical fertilizer (urea), synthetic detergent (Nirma washing powder), insecticides and pesticides (DDT and malathion) on 5 '-nucleotidase, an important hydrolytic enzyme in the liver, kidney, intestine and gills of a fresh water teleost, Heteropneustes fossilis.

\section{MATERIALS AND METHOD}

The body of water under investigation is one of the biggest in northern India and is known as Panchanada, where five large and very important rivers of the country viz., Yamuna, Chambal, Kuwanri, Send and Pahuj meet together, preserving the precious aquatic fauna mainly the great crocodiles, terrapins, turtles and a variety of fish fauna. For the present experimental set up the in situ concentrations of different contaminants and pollutants were first analysed in the fish Heteropneustes fossilis. The four common contaminants and pollutants viz. Urea (a chemical fertilizer), Nirma (a synthetic detergent), DDT (an insecticide) and malathion (a pesticide) which find their way into the water body from the catchment areas through human practices and rain water, were finally selected for syneristic treatment. The median tolerance limits (T1m or TL 50 value) were calculated as represented in the Graph I and Table 1. The methods adopted were those of Reed and Muenech as described by Michael (6).

Liver, Kidney, intestine and gills were dissected out from the normal and treated specimens of $H$. fossilis. They were cut into very small pieces of about $1 \mathrm{~mm}$ size and sections about $6-8 \mu \mathrm{m}$ thick were cut with a freezing microtome. For 5 '-nucleotidase activity, the calcium method as described by Pearse (7) was followed. $0.04 \mathrm{M}$-adenylic acid (adenosine-5-phoshate) from Sigma Chem. Co. Ltd. was used as a substrate. Control experiments were also run side by side. 
TABLE 1. Table showing percent mortality of the fish heteropneustes fossilis treated with varied concentrations of mixed tocixants

\begin{tabular}{|c|c|c|c|c|c|c|c|c|}
\hline $\begin{array}{c}\text { Ecological } \\
\text { Amplitude } \\
\text { Concentration } \\
\text { mg/l }\end{array}$ & $\begin{array}{l}\text { No. of } \\
\text { Animals }\end{array}$ & $\begin{array}{l}\text { No. of } \\
\text { Deaths }\end{array}$ & $\begin{array}{l}\text { No. of } \\
\text { Survivals }\end{array}$ & $\begin{array}{c}\text { Accumulated } \\
\text { Deaths }\end{array}$ & $\begin{array}{l}\text { Accumulated } \\
\text { Survival }\end{array}$ & Total & $\begin{array}{c}\text { Mortality } \\
\text { Ratio }\end{array}$ & $\begin{array}{l}\text { Percent } \\
\text { Mortality }\end{array}$ \\
\hline 1 & 2 & 3 & 4 & 5 & 6 & 7 & 8 & 9 \\
\hline 0.1 & 10 & 0 & 10 & 0 & 29 & 29 & - & 一 \\
\hline 0.2 & 10 & 1 & 9 & 1 & 19 & 20 & $1 / 20$ & $5 \%$ \\
\hline 0.3 & 10 & 4 & 6 & 5 & 10 & 15 & $5 / 15$ & $33 \%$ \\
\hline 0.4 & 10 & 7 & 3 & 12 & 4 & 16 & $12 / 16$ & $75 \%$ \\
\hline 0.5 & 10 & 9 & 1 & 21 & 1 & 22 & $12 / 22$ & $95 \%$ \\
\hline
\end{tabular}

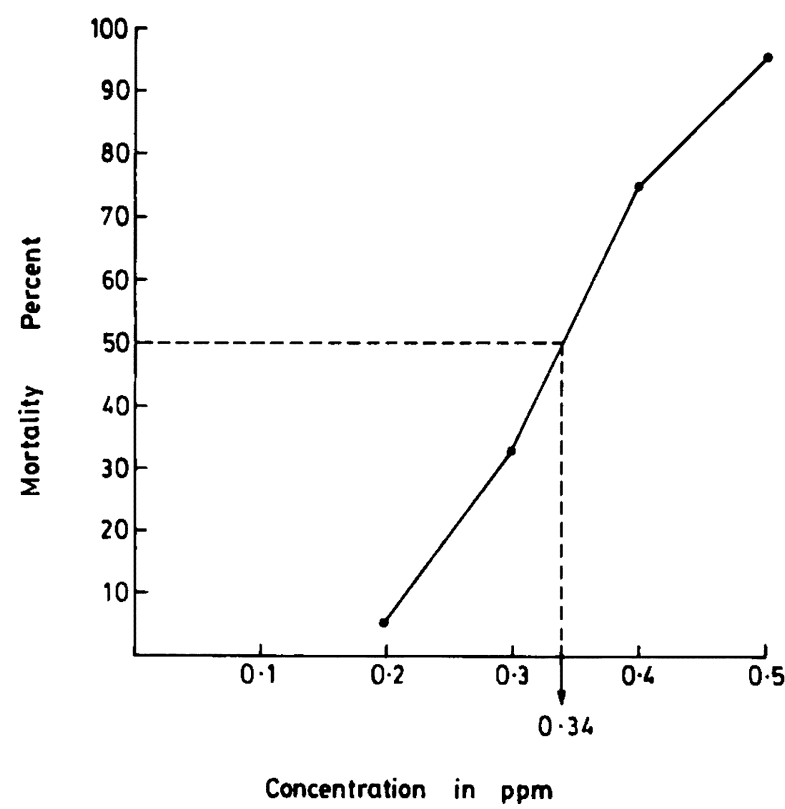

\section{RESULTS}

Treatment of toxicants, at first results in an increased 5 -nucleotidase activity in the liver cells (PlateI, Fig. 1), however, prolonged exposure (30-90 days) caused little decease in the intensity of 5 -nucleotidase reaction product. Enzyme activity was noticeable at the periphery of the hepatocytes, nuclei and interlobular spaces (Plate-II, Fig. 1). No 5'nucleotidase reaction product could be observed in the uriniferous tubules and haemopoietic tissue of the kidney of normal specimens, however, at the basement membrane appreciable enzyme activity was confirmed (Plate-I, Fig. 2). In the treated specimens the enzyme activity was elevated and the enzyme active sites were altered (Plate-II, Fig. 2).

Low doses and short term exposure resulted in significant enhancement of 5 '-nucleotidase activity mainly in the goblet cells, columnar epithelium and submucosa (Plate-I, Fig. 3). High dose and long term exposure confined the reaction product only at specific sites of the intestinal mucosa (Plate-II, Fig. 3). In the gills a marked synergistic effect was noted. The presence of dense deposits of 5 '-nucleotidase reaction product in the pillar cells of alternate gill lamina wsa confined to the middle of the primary gill lamellae (Plate-II, Fig. 4), while in normal conditions the activity was low and the reaction product was noted at other sites (Plate-I, Fig. 4).

No enzyme activity could be noted in control experiments (Plate-III, Figs. 1-3, 4) in the four tissues under study.

\section{DISUSSION}

The different contaminants and pollutants at sub- 

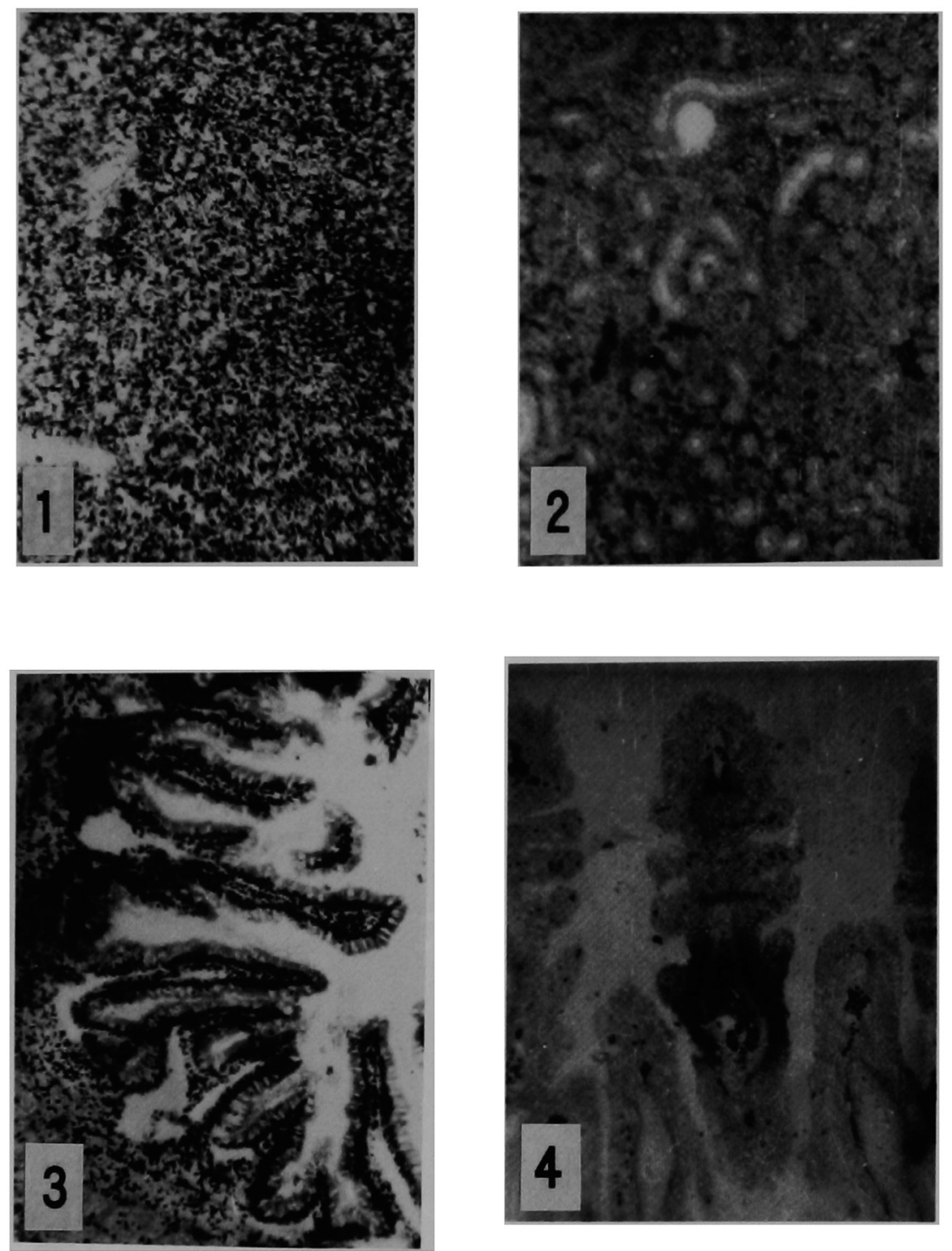

Ptate-I

FIG. 1. T. S. of liver of Heteropneustes fossilis showing 5'-nucleotidase activity after 10 days exposure to combination of urea, Nirma, DDT and Maltathion. $\times 400$

FIG. 2. $5^{\prime}$-nucleotidase activity in the kidney of $H$. fossilis in transerverse section under normal conditions. Enzyme reaction product can be seen at the basement membrane of kidney tubule cells. $\quad \times 600$

FIG. 3. T.S. of intestine of $H$. fossilis. Dense deposits of enzyme reaction product are visible in the goblet cells, columnar epithelium and submucosa at low doses and short term exposure. $\quad \times 600$

FIG. 4. T. S. of gill of $H$. fossilis showing 5 -nucleotidase activity under normal conditions. Weak activity is visible in both the primary and secondary gill lamellae and the pillar cells. $\times 400$

lethal levels affected $5^{\prime}$-nucleotidase activity in various tissues of Heteropneustes fossilis in the present investigation. Significant stimulation of enzyme activity was observed in the kidney. In the gills, however, the alterations were more marked. Long term exposure to these chemicals led to the shifting of enzyme active sites from the normal course and was restricted to the centre of the primary gill lamellae of alternate gill filaments. At other places no trace of 5 -nucleotidase reaction product could be confirmed. Gupta et al. (3) have also observed the inhibition of 5 '-nucleotidase activity in liver, kidney, gills and brain of a fresh water teleost Notopterus notopterus after 15 and 30 days of exposure to sublethal concentrations of phenolic com- 

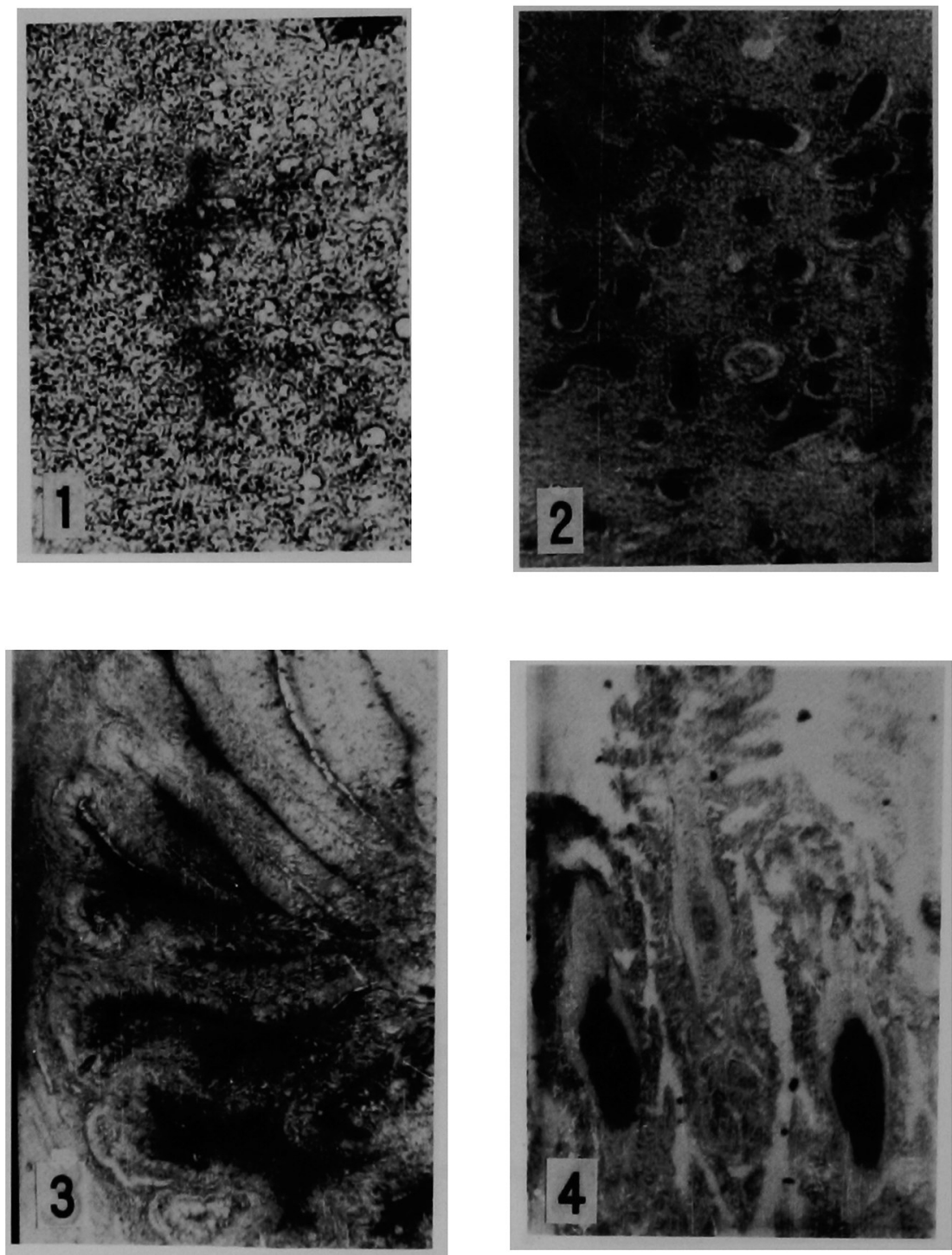

Plate-II

Fig. 1. T. S. of $H$. fossilis. Prolonged exposure to the toxicants inhibits 5 '-nucleotidase activity. $\times 600$

FIG. 2. T. S. of kindney of $H$. fossilis showing high enzyme activity after 60 days exposure to toxicants. The activity is mainly in the lumen of the tubules. $\times 400$

Fig. 3. 5'-nucleotidase activity in the transeverse section of the intestine of $H$. fossilis. Reaction product only at specific sites. $\times 600$

FIG. 4. T. S. of gill of $H$. fossilis showing 5'-nucleotidase activity. Dense deposits of reaction product can be clearly seen in the middle of the alternate gill lamina. $\times 400$

pounds. Synergistic treatment, however, showed significant stimulation of this enzyme in the kidney. The have expressed the view that the inhibition of this enzyme in tissues possibly represents the uncoupling of oxidative phosphorylation, while stimulation of the enzyme indicates that the concerned chemical compounds might be inducing the cells to produce more of this enzyme. Our observations on the activity of 5'- nucleotidase in the cells of four different tissues of the fish do not fully support the views of above workers. In fact the cells have different physiology in the different tissues in different conditions. For instance, in the case of excretory cells of the kidney the concentration of the enzyme in the lumen of the tubules hardly has any relationship with the enzyme activity outside the cell. It could possibly be a means adapted by 

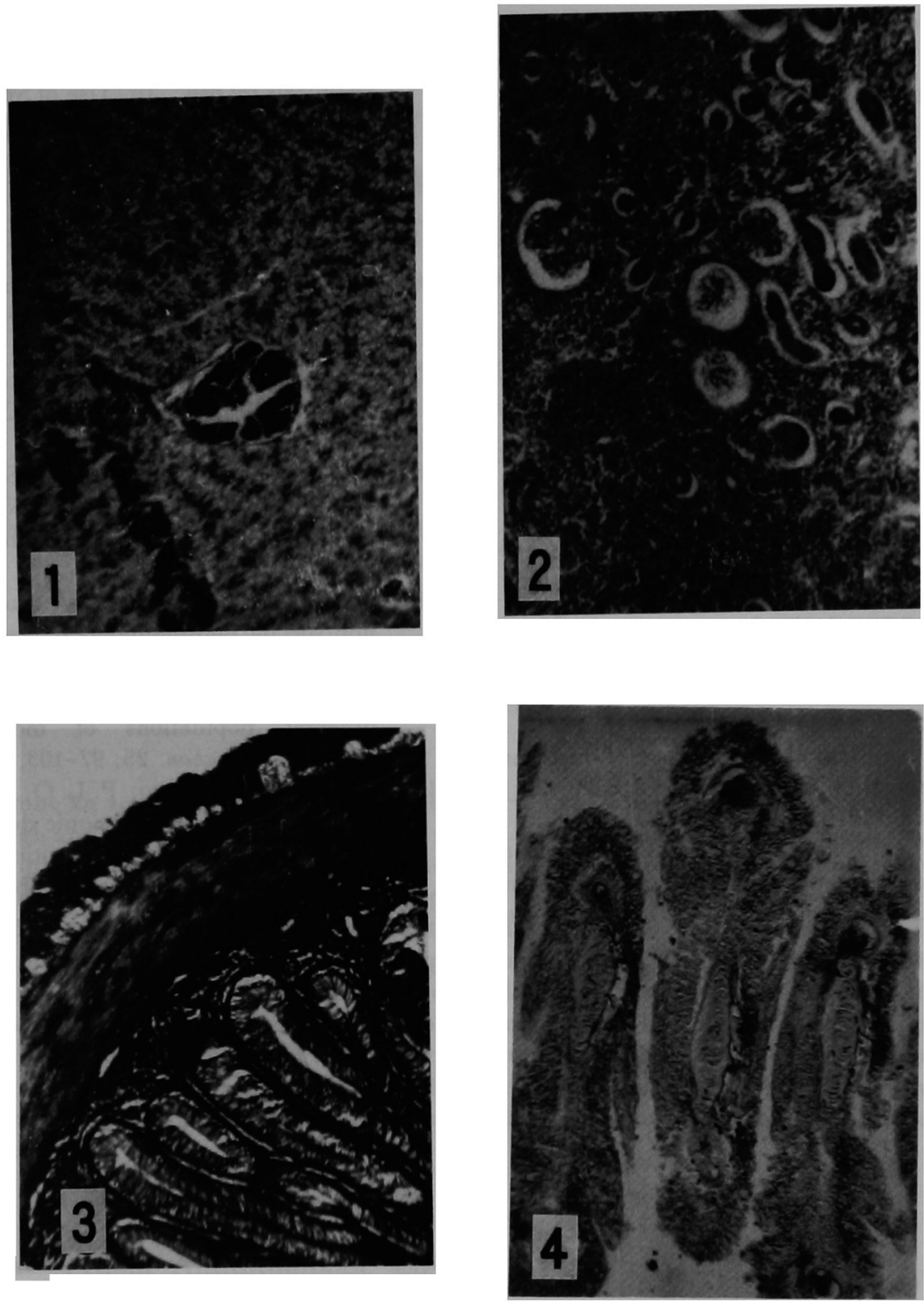

Plate-III

Fic. 1. T. S. of liver of $H$. fossilis No enzyme activity was noticed at a pH of $9.0 . \quad \times 400$

FIG. 2. T. S. of Kidney of $H$. fossilis Omission of calcium nitrate resulted in negative $5^{\prime}$-nucleotidase activity. $\times 400$

Fic. 3. T. S. of intestine of $H$. fossilis. Reaction produt is not formed when adenylic acid omitted from the incubating medium. $\times 600$

Fig. 4. T.S. of gill in control specimens. Omission of adenylic acid produced no enzymatic reaction. $\times 600$

excretory cells to expel the foreign substance and toxic agent outside the system of the organism by certain process of transport from the cells towards the lumen. Zaccone et al. (11) and Mehra and Kanwar (5) have also noted marked alterations in enzyme activities and suggested that the fish tissues may provide a suitable experimental model for cytochemical investigations of the effects of stress induced by pollutants on aquatic organisms.

Uusitalo et al. (10) and Chowdhury (2) also studied $5^{\prime}$-nucleotidase activity in different tissues of vertebrates under the influence of xenobiotics and noted the role of $5^{\prime}$-nucleotidase as the membrane bound enzyme in specific cell types. In the present investigations not only a significant alteration in $5^{\prime}$ nucleotidase active sites were noteworthy, the enzyme 
activity exhibited a remarkable feature in leaving the area of operation by leaving the membrane system of its anchorage due to intake of contaminants and pollutants. The activity of the enzyme molecule in the biological system is influenced in a large measure by topographical or conformational changes in the enzyme molecule-more so in keeping with the physiology of the cells. Accrodingly the enzyme activity must be viewed in this perspective as well.

\section{ACKNOWLEDGMENTS}

Financial assistance from Ministry of Science and Technology, Government of India through project no. 21 (69)/84 STP-I, is gratefully acknowledged.

\section{REFERENCES}

1. Abel, P. D.: Toxicity of synthetic detergents to fish and aquatic invertebrates. J. Fish Biol. 6; 279-284, 1974.

2. Chowdhury, A.R.: Methodological role of histochemistry in the research of reproductive toxicology. $J$. Histochem. Cytochem. 36; 910, 1988.

3. Gupta, S., Dalela, R. C. and Saxena, P. K.: Effects of phenolic compounds on 5 '-nucleotidase activity in some tissues of Notopterus notopterus (Pallas). Toxicology Letters
$17 ; 167-173,1983$.

4. John, J. L. and Vodicnik, M. J.: Biotransformation of chemicals by fish. In "Use of Small Fish Species in Carcinogenicity Testing," NIH-publication no. 84-2653 Bethesda, Maryland, 1984, p. 355-358.

5. Mehra, M. and Kanwar, K. C.: Enzyme changes in the brain, liver and kidney following repeated administration of mercuric chloride. JEPTO. 7; 65-72, 1986.

6. Michael, P.: Ecological methods for field and laboratory investigations. Tata Nc Graw-Hill Publishing Co. Ltd., New Delhi, 1984.

7. Pearse, A. G. E.: Histochemistry, Theoretical and Applied, vol. 2, 3rd Ed., J. \& A. Churchill, Ltd., London, 1972.

8. Richard, R. N. B. and Bajpai, S.: Studies on some environmental factors of Daurs, North Bengal, in relation with epizootic ulcerative syndrome on fresh water fishes. Bioved. 1; 125-132, 1991.

9. Shaff, S. A.: DDT toxicity: gluconeogenic enzymes and non-specific phosphomonoesterases in three teleosts. Acta Physiol. 53; 501-506, 1982.

10. Uusitalo, R.J. and Karnovsky, M. J.: 5'-nucleotidase in different populations of mouse lymphocytes. $J$. Histochem. Cytochem. 25; 97-103, 1977.

11. Zaccone, G., Cascio, P. L. O., Fasulo, S. and Licata, A.: The effect of an anionic detergent on complex carbohydrates and enzyme activities in the epidermis of the cat fish Heteropneustes fossilis (Bloch). Histochem. J. 17; 453-466, 1985. 